JOURNAL OF APPLIED SMART ELECTRICAL
NETWORK AND SYSTEMS (JASENS)
ISAS

\title{
Analisa Dan Evaluasi Kinerja ATS Pada Pelanggan Premium Tegangan Menengah di PT. PLN UP3 Gresik
}

\author{
Mohammad ilham ${ }^{1,}$ Abdul Ghofar Romdhon ${ }^{2}$, Rini Puji Astutik ${ }^{3}$, Denny Irawan ${ }^{4}$ \\ 1,2,3,4) Jurusan Teknik Elektro, Universitas Muhammadiyah Gresik \\ 1ilham_170603@umg.ac.id.2abdulghofar_170603@umg.ac.id.3astutik_rpa@umg.ac.id 4den2mas@umg.ac.id
}

\begin{abstract}
In an effort to meet customer needs on supplying electricity in the industrial era 5.0, it needs to have good services which keep growing up and be innovative. One of them is running a premium service which guarantees better quality of service than that of the regular. This research will discuss all of the obstacles that can disrupt the continuity of electricity supply to the customer with premium services, starting from the disruptions at the supply side until at the installation owned by the customer. From the analysis result, ATS (Automatic Transfer Switch) failed several times on working so that caused a black out at the customer side which it should be avoided. Therefore, it is necessary to make some adjustments on setting and wiring to some problems which may arise so that the potential disruption of the ATS or equipment failure can be suppressed. This research aims to minimize and even eliminate ATS performance failures due to system disturbances by implementing rewiring, adding a permissive interlocking system and adding a PLC with a time delay setting.
\end{abstract}

Keywords: ATS, power outages.

\begin{abstract}
Abstrak
Dalam upaya memenuhi kebutuhan pelanggan akan pasokan energi listrik di era industri 5.0 ini memerlukan layanan yang terus berkembang dan inovatif, salah satunya dengan di jalankannya layanan premium yang menjamin kualitas pasokan menjadi lebih baik daripada layanan reguler. Penelitian ini membahas segala kendala yang timbul dan dapat menggangu kelangsungan pasokan energi listrik kepada pelanggan dengan tarif premium, mulai dari gangguan sisi pasokan hingga gangguan sisi instalasi milik pelanggan. Dari hasil analisa peraltan ATS (Automatic Transfer Switch) telah beberapa kali gagal kerja sehingga menimbulkan Black Out pada sisi pelanggan yang seharusnya dapat dihindari, oleh sebab itu perlu dilakukan beberapa penyesuaian pada setting dan wiring terhadap beberapa permasalahan yang timbul sehingga dapat menekan potensi terganggunya ATS maupun kegagalan kerja peralatan. Penelitian ini bertujuan untuk meminimalisir bahkan menghilangkan kegagalan kineja ATS akibat gangguan pada sistem dengan cara melaksanakan rewiring, menambahkan sistem interlocking permisive dan menambahkan PLC dengan setting time delay.
\end{abstract}

Kata kunci: ATS, gangguan pasokan listrik.

Diterima Redaksi : 16-11-2020 | Selesai Revisi : 21-12-2020 | Diterbitkan Online : 31-12-2020

\section{Pendahuluan}

PT PLN (Persero) adalah perusahaan jasa pelayanan penyediaan tenaga listrik. PLN membangkitkan tenaga listrik, menyalurkan dan mendistribusikan kepada para pelanggan. Produksi PLN yang berupa energi listrik, kemudian dimanfaatkan oleh pelanggan untuk berbagai keperluan kehidupannya, antara lain sebagai sumber energi penerangan, sumber energi mekanik, dan sebagainya.

Demikian pentingnya tenaga listrik dalam kehidupan masyarakat tergantung dan terikatnya dengan tenaga listrik, maka listrik saat sekarang telah menjadi kebutuhan utama (primer) bagi masyarakat. Tidak dapat dibayangkan apabila penyaluran tenaga listrik disebuah kota harus terputus dalam satu hari, berbagai aktivitas kehidupan akan terganggu bahkan akan terhenti sama sekali.
Sangat pentingnya listrik bagi kehidupan, maka PT. PLN (Persero) senantiasa meningkatkan mutu pelayanan kepada pelanggan, dalam sistem distribusi tenaga listrik, permasalahan pada umumnya adalah pada mutu, kontinuitas, dan ketersediaan pelayanan daya listrik pada pelanggan. PT.PLN (Persero) sebagai perusahaan yang bergerak dalam bidang penyediaan energi listrik dimana salah satu tujuannya adalah untuk memenuhi kebutuhan energi listrik ke konsumen, memiliki andil yang sangat besar untuk memberikan jaminan kualitas penyaluran energi listrik yang memenuhi standar baik secara teknis maupun non-teknis kepada konsumen.

Dalam hal ini PLN menyediakan satu layanan yang mempunyai keunggulan dibanding layanan reguler biasa yaitu layanan premium dimana layanan tersebut lebih menjamin keberlangsungan supply tenaga listrik kepada konsumen, tentunya dengan harga yang lain daripada 
layanan reguler. Untuk mendukung layanan premium Dari beberapa dasar yang telah dijelaskan diatas maka pada beberapa pelanggan tersebut PLN menggunakan 2 tujuan penelitian ini adalah:

sumber dari trafo Gardu Induk yang berbeda serta pada gardu Cubicle yang dipasang pada pelanggan juga di lengkapi dengan sistem ATS (Automatic Transfer Switch) yang memungkinkan supply akan berpindah secara otomatis bila supply utama mengalami gangguan. Untuk di wilayah kerja UP3 Gresik yang sudah menggunakan sistem tersebut diantaranya adalah Gressmall dan Iconmall [1].

Dalam perjalanan operasinya ATS tersebut tak jarang mengalami permasalahan kegagalan switch dan Dalam menyusun penelitian ini diperlukan adanya flow berdampak pada terhentinya supply aliran listrik kepada chart agar dapat berjalan sesuai dengan perencanaan pelanggan. Hal tersebut sangat merugikan dari kedua dalam flow chart dan memudahkan untuk melaksanakan belah pihak baik dari sisi pelanggan yaitu dengan rencana tersebut. Alur metodologi penyelesaian jurnal terhentinya proses produksi maupun dari sisi PLN yang penelitian ini dapat digambarkan dalam flow chart

terkena konsekuensi dari hal tersebut yaitu berupa denda gambar 1:

yang harus dibayarkan kepada pelanggan. Di latar belakangi oleh hal tersebut maka penulis bermaksud untuk melakukan analisa terhadap segala penyebab yang dapat memicu kegagalan dari proses perpindahan atau Switching tersebut sehingga untuk selanjutnya dapat ditemukan solusi untuk menghindari kerugian akibat kegagalan ATS dalam bekerja. Beberapa jurnal yang membahas hal ini antara lain :

1. "Automatic transfer Switch (ATS) Using Pogrammable Logic Controller (PLC)" oleh Dr. Hamdy Ashour [2]

2. "Automatic Transfer Switch (Sebuah Tinjauan)" Oleh Eko Susanto [3].

3. "Rancang Bangun Automatic Transfer Switch (Ats) Dengan Parameter Arus, Frekuensi Dan Suhu" oleh Yudi Fikra [4]

4. "Perancangan Automatic Transfer Switch (Ats) Parameter Transisi Berupa Tegangan Dan Frekuensi Dengan Mikrokontroler Atmega 16" oleh Pul Hendry Ginting [5]

5. "Sistem Automatic Transfer Switch (Ats) Automatic Main Failure (Amf) Menggunakan Sms" oleh Inta Maryanto [6]

6. "Rancang Bangun Dan Implementasi Automatic Transfer Switch (Ats) Menggunakan Arduino Uno Dan Relai" oleh Robinzon Pakpahan [7]

Salah satu Visi Distribusi 2012 adalah PLN harus dapat menyediakan listrik yang berkualitas atau bermutu. Apakah mutu listrik itu sebenarnya? Power Quality sering dipersepsikan sebagai kualitas layanan listrik yang harus disediakan oleh PLN ke pelanggannya. Pengertian ini kurang tepat, karena bila demikian lebih sesuai dengan istilah Service Quality. Power Quality lebih bersifat teknikal,yaitu menyangkut mutu tegangan dan mutu arus listrik. Lebih jelasnya ukuran mutu tadi terdiri dari tiga hal,yaitu [8] :

1) Bentuk gelombang

2) Besar amplitudo atau magnitude

3) Nilai frekuensi,baik nilai satu gelombang penuh maupun nilai setengah gelombang.

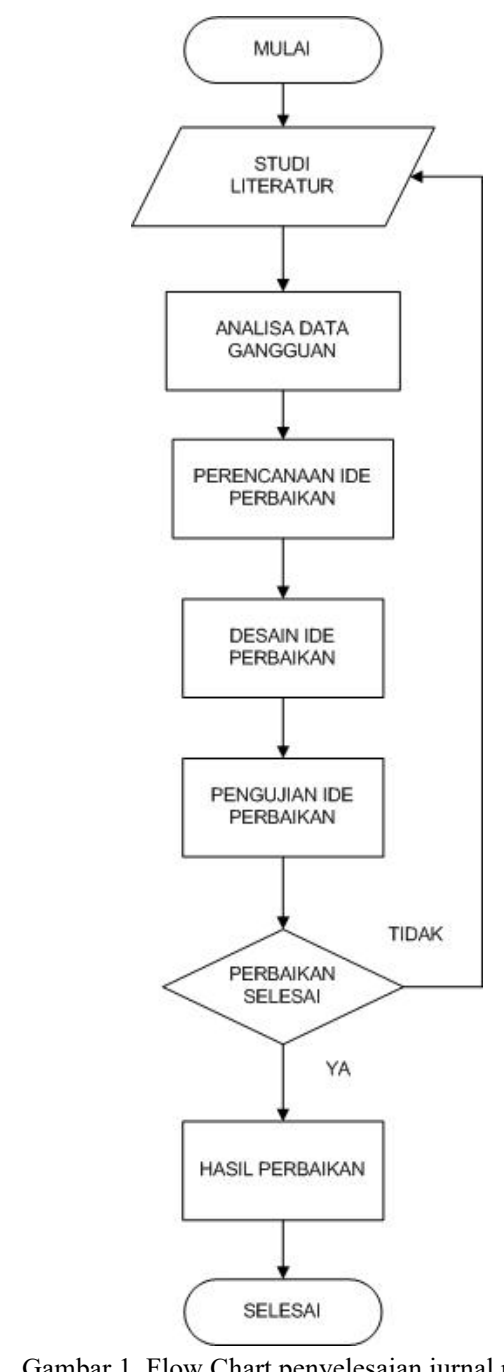

Gambar 1. Flow Chart penyelesaian jurnal penelitian

pada ATS.

2. Melakukan analisa dan evaluasi terhadap sistem ATS yang ada saat ini.

3. Merancang solusi dan ide perbaikan terhadap permasalahan ATS sehingga dapat menigkatkan efektifitas dan kehandalan peralatan tersebut.

\section{Metode Penelitian}




\subsection{Studi Literatur}

Metode penelitian dimulai dengan studi literatur, yaitu mencari informasi melalui buku-buku, jurnal, artikel, dan internet yang berhubungan dengan elemen-elemen yang dipakai dalam penelitian ini. Sumber langsung didapatkan dari hasil diskusi maupun konsultasi dengan dosen atau orang yang mempunyai kompetensi di bidang ini. Adapun literatur-literatur yang dipelajari adalah

\section{a. Electrical Power Systems Quality \\ b.Programmable Logic Controller (PLC)}

Programmable Logic Controller (PLC) adalah sebuah rangkaian elektronik yang dapat mengerjakan berbagai fungsi-fungsi kontrol pada level-level yang kompleks. PLC dapat diprogram, dikontrol, dan dioperasikan oleh operator yang tidak berpengalaman dalam mengoperasikan komputer [9]. PLC umumnya digambarkan dengan garis dan peralatan pada sebuah diagram ladder. Hasil gambar tersebut pada komputer menggambarkan hubungan yang diperlukan untuk sebuah proses. PLC akan mengoperasikan semua siatem yang mempunyai output apakah harus ON atau OFF. Dapat juga dioperasikan sebuah sistem dengan output yang bervariasi.Selain itu PLC juga menggunakan memory yang dapat diprogram untuk menyimpan instruksi-instruksi yang melaksanakan fungsi-fungsi khusus seperti: logika pewaktuan, sekuensial dan aritmetika yang dapat mengendalikan sebuah mesin atau proses melalui modul-modul I/O baik analog maupun digital [10].

\subsection{Analisa Data Gangguan}

Dalam menentukan metode perbaikan dan mendesain ide perbaikan sebagai penyelesaian atas permasalahan dalam skripsi ini diperlukan analisa data gangguan menentukan pokok masalah sehingga dapat ditentukan ide perbaikan yang sesuai. Data gangguan yang diperlukan diantaranya seperti yang ditunjukkan pada tabel 1 [11] sebagai berikut:

Tabel 1. Tabel data Gangguan

\begin{tabular}{|c|c|c|c|c|c|}
\hline No & Tanggal & Penyulang & Jam & Relay & Akibat yang ditimbulkan \\
\hline 1 & $11 / 02 / 2019$ & Suci & $22: 52: 00$ & OCR & Icon Mall gagal switch \\
\hline 2 & $17 / 02 / 2019$ & Panca Putra & 9:00:00 & OCR-INST & Petro Oxo \& Bumi Mulia dip \\
\hline 3 & $25 / 02 / 2019$ & Suci & 11:52:00 & DGR & Gresmall Gagal switch \\
\hline 4 & $13 / 03 / 2019$ & Tridharma & $16: 33: 00$ & OCR-INST & Petro Oxo \& Bumi Mulia dip \\
\hline 5 & $31 / 12 / 2019$ & Suci & $21: 23: 00$ & EF & Gresmall Gagal switch \\
\hline 6 & $10 / 01 / 2020$ & Suci & $22: 07: 00$ & EF & Gresmall Gagal switch \\
\hline 7 & $25 / 02 / 2020$ & Panca Putra & $16: 43: 00$ & OCR-INST & Bumi Mulia gagal Switch \\
\hline 8 & $08 / 04 / 2020$ & Suci & $22: 21: 00$ & $\mathrm{EF}$ & Gresmall Gagal switch \\
\hline 9 & $09 / 05 / 2020$ & Panca Putra & $10: 22: 00$ & OCR-INST & Petro Oxo \& Bumi Mulia dip \\
\hline 10 & $10-06-2020$ & Patra Raya & 10:03:00 & OCR-INST & Putro Lingkungan gagal switch \\
\hline
\end{tabular}

Setelah didapatkan data-data tersebut maka dimulailah mencari pokok permasalahan dengan menggunakan metode Root Cause Problem Solving (RCPS) sehingga dapat dipetakan akar penyebab permasalahan. Dari akar permasalahan tersebut akan dapat dimunculkan ide perbaikan.

\subsection{Root Cause Problem Solving (RCPS)}

Root Cause Problem Solving seperti yang ditunjukkan pada gambar 2 adalah sebuah metode yang digunakan untuk mencari akar dari sebuah permasalahan. Teknik ini dapat digunakan untuk mencari penyebab-penyebab dari suatu permasalahan. Tantangan dari penerapan metode ini adalah peneliti harus mampu membedakan antara gejala masalah dengan penyebabnya [12]. Dalam kasus ini untuk RCPS yang digunakan adalah sebagai berikut:

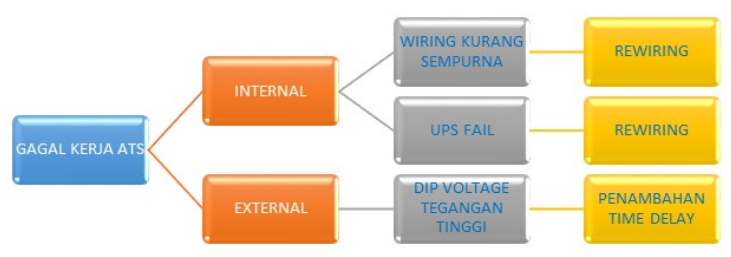

Gambar 2. RCPS (Root Cause problem Solving)

\subsection{Perancangan Perbaikan}

Pada tahap ini dilakukan pembuatan perancangan perbaikan yang didasarkan pada akar permasalahan, metode yang digunakan dalam menentukan perbaikan adalah dengan menggunakan metode matriks prioritas dimana metode tersebut memetakan perbaikan berdasarkan tingkat kemudahan pelaksanaan tersebut dan dampaknya terhadap penanganan permasalahan.

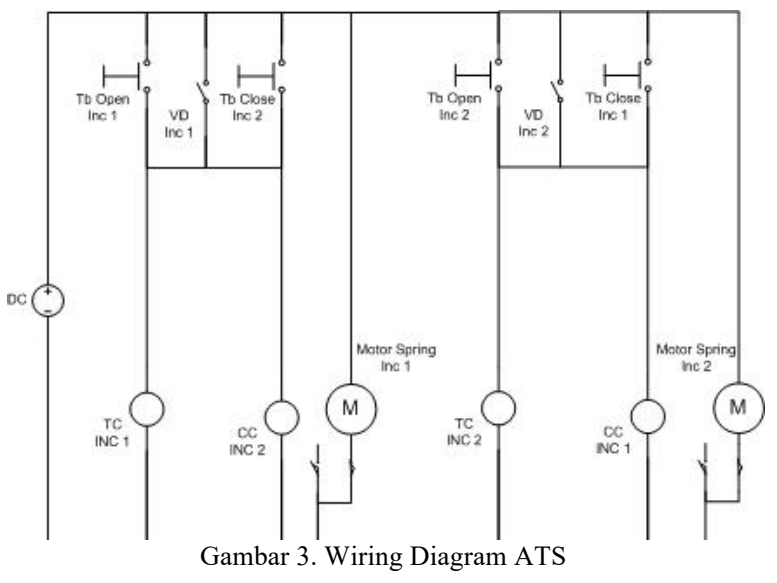

Perbaikan yang akan kita terapkan adalah perbaikan yang memenuhi persyaratan Low Cost High Impact (mudah diterapkan/berbiaya rendah tetapi memiliki efektifitas tinggi dalam dampaknya terhadap penanganan permasalahan).

Desain perbaikan yang dilaksanakan dimulai dari identifikasi kekurangan sistem kerja ATS yang sudah ada dengan wiring diagram seperti pada gambar 3 dan menambahkan perbaikan kita mulai dari perubahan wiring diagram, menambahkan peralatan PLC untuk menyempurnakan sistem kerja ATS yang ada dan juga menambahkan power supply sehingga dapat menjamin 
peralatan ATS dapat bekerja meski terdapat gangguan berlaku yaitu untuk power supply berupa UPS terbebani pada supply tegangan sesaat. Pada wiring diagram diatas oleh peralatan kontrol berupa sensor tegangan VD, Coil memiliki beberapa kekurangan:

trip \& open, lampu indikator serta motor untuk spring. Pada identifikasi kami pada saat supply penyulang

1. Belum adanya permisive interlock sehingga utama mengalami gangguan hal itu menyebabkan memungkinkan incoming 1 dan incoming 2 akan tegangan pada penyulang utama menjadi turun bahkan paralel sesaat.

dapat mencapai $0 \mathrm{kV}$, itu akan mengaktifkan sensor

2. Belum adanya permisive pada motor memungkinkan tegangan dan akan memerintahkan melepas Circuit motor dan coil bekerja bersamaan sehingga Breaker (CB) pada incoming penyulang utama untuk menyebabkan tegangan drop, dapat mengganggu kemudian memerintahkan masuk CB pada incoming sinyal ke coil. penyulang backup. Perintah tersebut terganggu karena pada saat penyulang utama padam maka sumber Skema single diagram pada gambar 4 merupakan skema 220VAC akan turut padam sehingga backup power umum yang diterapkan untuk sebagian besar pelanggan supply berupa UPS akan bekerja, sayangnya pada saat premium dengan alur kerja ATS seperti yang UPS tersebut bekerja, UPS menanggung beban peralatan ditunjukkan pada gambar 5 .

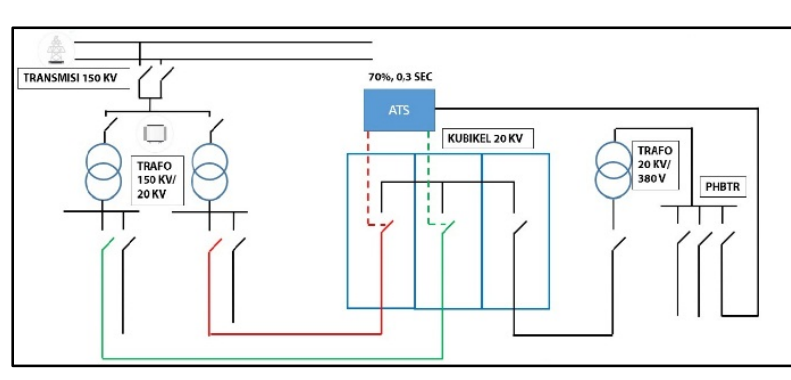

Gambar 4. Single line Diagram

Dari alur kerja tersebut akan ditambahkan peralatan PLC dan dilakukan perubahan Wiring Diagram, maka akan disusun desain Wiring Diagram yang baru dan juga disusun Ladder Diagram pada PLC untuk memenuhi kebutuhan perbaikan tersebut.

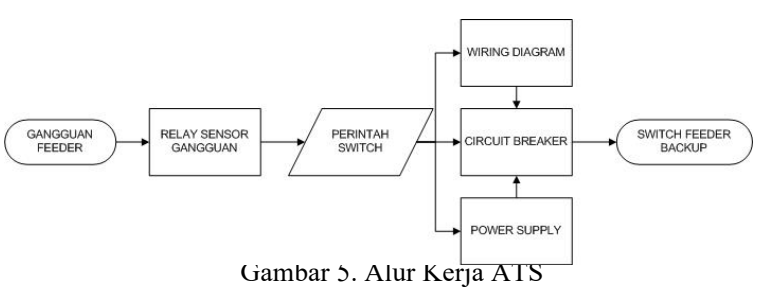

Disamping rencana solusi diatas terdapat rencana pemecahan masalah yang ke dua yaitu dengan penggunaan DRUPS (Diesel Rotary Uninterruptible Power Supply) tentunya peralatan ini juga mempunyai kelebihan maupun kelemahan, maka dari itu kami akan menganalisa dan hasilnya dijadikan sebagai usulan kepada perusahaan sebagai solusi atas permasalahn ATS yang ada.

\section{Hasil dan Pembahasan}

Dari beberapa permasalahan dan identifikasi diatas terdapat 3 hal yang akan dijadikan topik utama dalam evaluasi kinerja dari ATS yaitu:

\subsection{Rewiring}

Pelaksanaan wiring ulang berdasarkan beberapa masalah yang ada seperti ditunjukkan pada gambar 6 . Untuk peralatan ATS yang ada saat ini wiring yang kontrol beserta dengan beban untuk motor spring dimana beban untuk motor spring jauh lebih besar dan mengakibatkan UPS tersebut drop. Drop pada UPS tersebut mengakibatkan kontrol mati dan pada akhirnya ATS gagal untuk bekerja.

Permasalahan wiring selanjutnya berada pada sisi interlock dimana wiring yang ada pada saat ini adalah untuk interlock belum sepenuhnya diterapkan sehiungga tidak adanya komunikasi berupa sinyal antara incoming 1 (penyulang utama) dengan interlock 2 (penyulang backup) hal tersebut mengakibatkan diantara incoming tersebut dapat berstatus close keduanya atau bahkan open keduanya. Operasi seperti itu sangat dihindari mengingat untuk sistem tidak diperbolehkan paralel dalam waktu yang lama karena hal tersebut sangat berpengaruh pada sistem di PLN yang dapat mengakibatkan terjadinya "power swing" diantara kedua trafo GI yang berbeda dan dapat berujung tripnya kedua penyulang yang di paralel.

Dari kedua permasalahan tersebut muncullah ide perbaikan yaitu:

1. Melakukan pemisahan wiring pada motor spring dimana motor spring hanya dapat bekerja apabila siklus switching dari penyulang utama (pelepasan) ke penyulang backup (pemasukan) telah berjalan sukses, kebutuhan untuk rewiring itu cukup sederhana dengan memindahkan power sping motor yang awalnya ikut perintah dari open penyulang utama, dipindahkan ke auxulury kontak pada penyulang backup saat sudah masuk dengan sukses (Auxulary contac NO).

2. Menerapkan sistem interlocking permisive dari penyulang utama terhadap penyulang backup. Dengan memanfaatkan Auxulary contact pada kedua penyulang maka interlocking permisive dapat dibuat dengan aturan bahwa sebelum penyulang utama lepas sempurna maka perintah untuk memasukkan penyulang kedua tidak akan bisa diterima oleh coil begitu sebaliknya. Hal tersebut dapat mencegah kedua incoming masuk atau lepas secara bersamaan. 


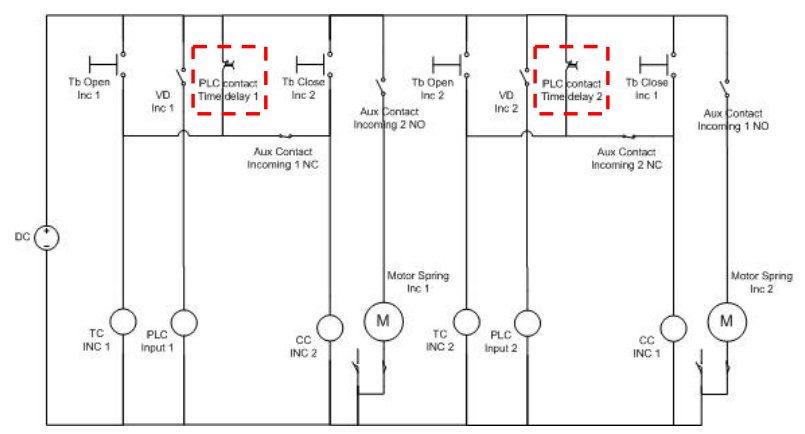

Gambar 6. Wiring Diagram setelah penambahan permisive dan time delay

\subsection{Penambahan Time Delay}

Perbaikan penambahan time delay ini berawal ketika terjadinya gangguan pada sisi transmisi tegangan tinggi (TT). Gangguan pada sisi tegangan tinggi tidak secara langsung dapat menimbulkan efek berupa padam apabila jalur tegangan tinggi yang terganggu tidak pada subsistem yang sama yang mensupplay penyulang utama atau penyulang backup. Umumnya kasus tersebut terjadi untuk gangguan TT yang bersifat temporer sehingga pada saat reclose sudah normal. Hal tersebut sesuai dengan teori interupsi, Interupsi adalah gangguan yang terjadi ketika tegangan suplai atau arus beban menurun sampai kurang dari 0,1 pu (per unit) untuk periode waktu tidak lebih dari 1 menit. Interupsi dapat oleh gangguan pada sistem sumber tenaga listrik. menjadi akibat dari kesalahan sistem tenaga listrik, Gambar 7 menunjukkan interupsi sesaat di mana jatuh kegagalan, dan terjadi kesalahan dari fungsi kendali. tegangan terjadi sekitar 20 persen selama 3 siklus dan Interupsi diukur dengan lamanya waktu terjadi kemudian turun menjadi nol sekitar 1,8 detik sampai gangguan, di mana besarnya tegangan yang terjadi pada recloser menutup kembali. saat gangguan selalu kurang dari 10 persen dari tegangan nominalnya. Lama terjadinya interupsi dikarenakan oleh gangguan pada sistem utilitas dan ditentukan oleh waktu pengoperasian dari peralatan proteksi. Peralatan proteksi (Penutup Balik Otomatis) pada umumnya akan membatasi interupsi disebabkan oleh gangguan non permanen kurang dari 30 siklus. Lamanya gangguan karena kesalahan fungsi peralatan atau koneksitas peralatan yang longgar atau kurang baik dapat terjadi secara tidak teratur [13].

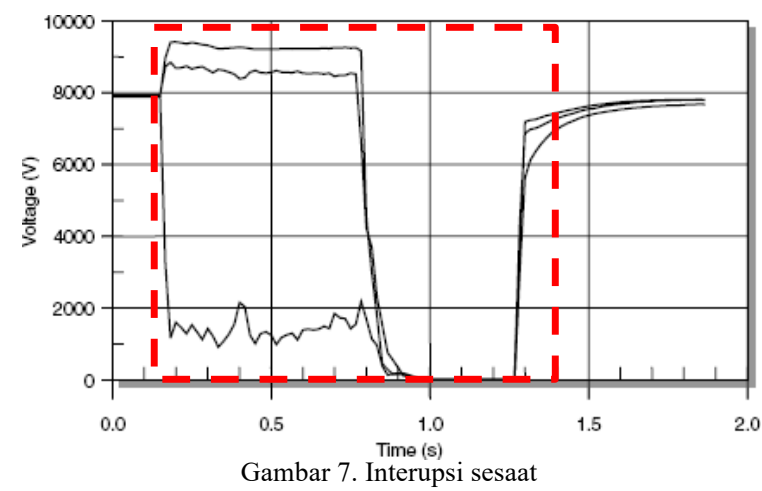

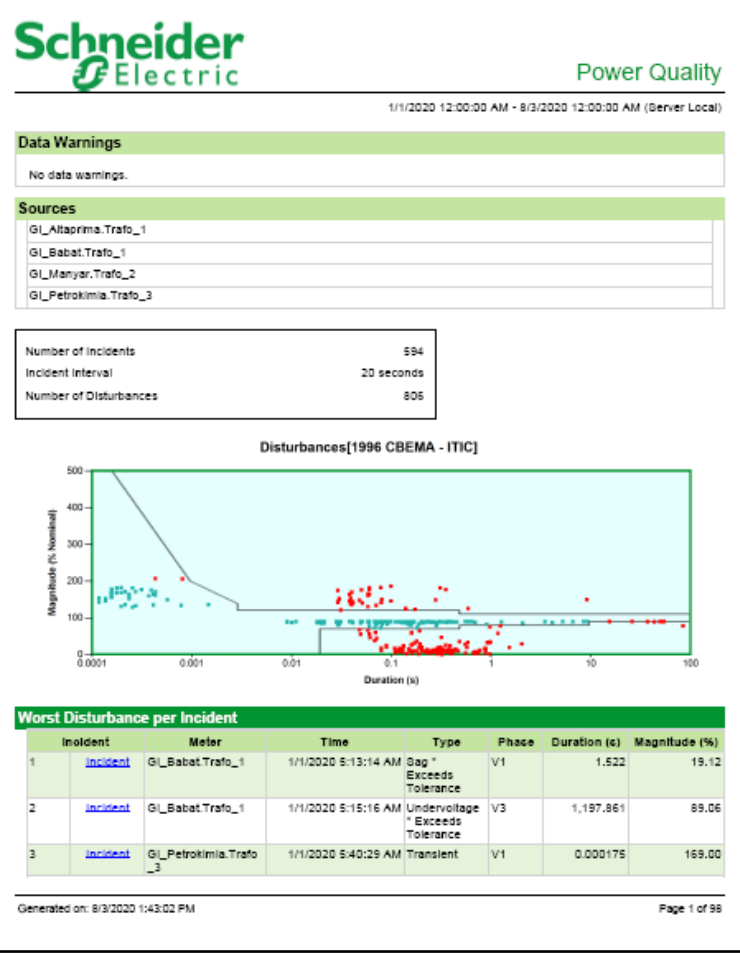

Gambar 8. Record gangguan TT bagian 1

Pada Gambar 8 pada GI Babat trafo 1 pada 1 Januari 2020 pukul 5:13:14 WIB terdapat record terjadinya dip voltage dalam waktu 1,522 detik dengan magnitude tegangan hanya tinggal $19,12 \%$ dari tegangan nominal $20 \mathrm{kV}$ (menjadi $3,8 \mathrm{kV}$ ) 


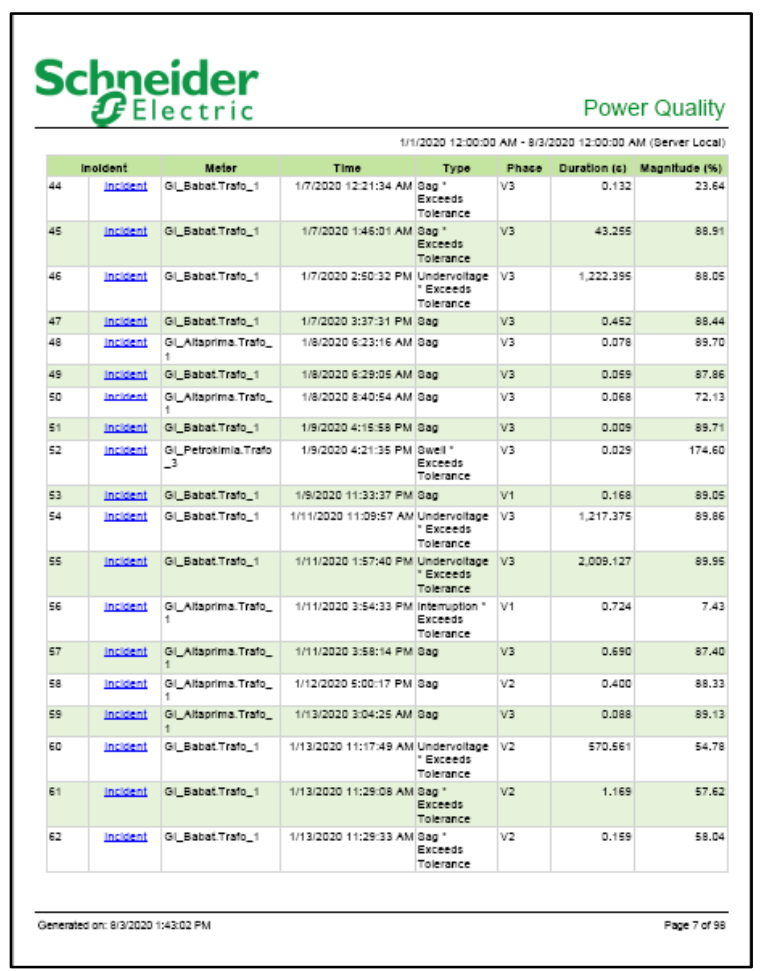

Gambar 9. Record gangguan TT bagian 2

Pada gambar 9 juga menunjukkan record serupa dengan gambar 8 yang terjadi di GI Babat dan GI Petrokimia

\section{Schneider}

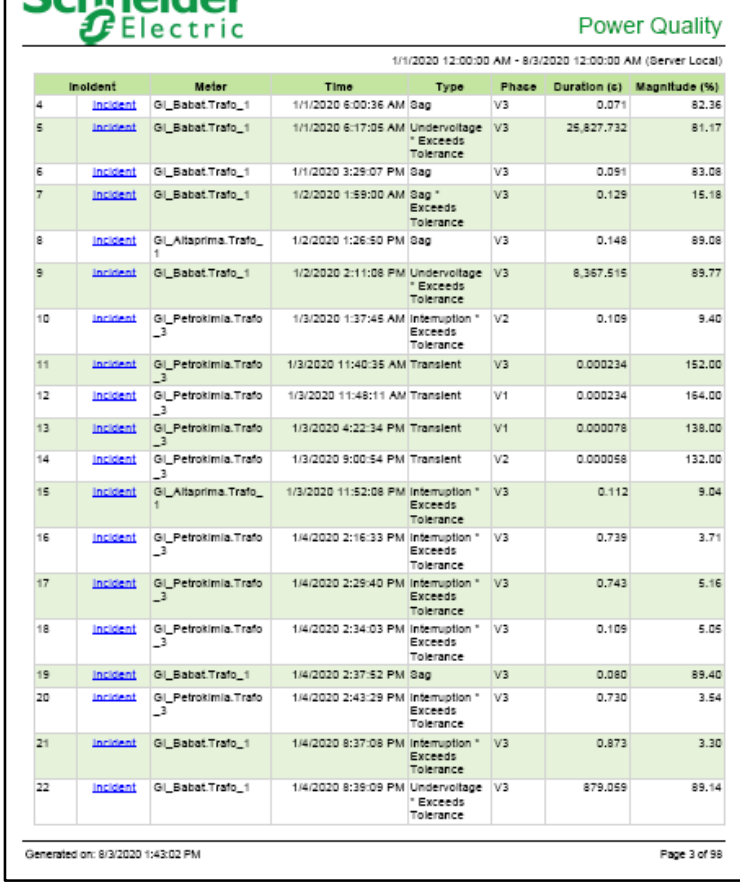

Gambar 10. Record gangguan TT bagian 3

\section{Schneider}

Power Quality

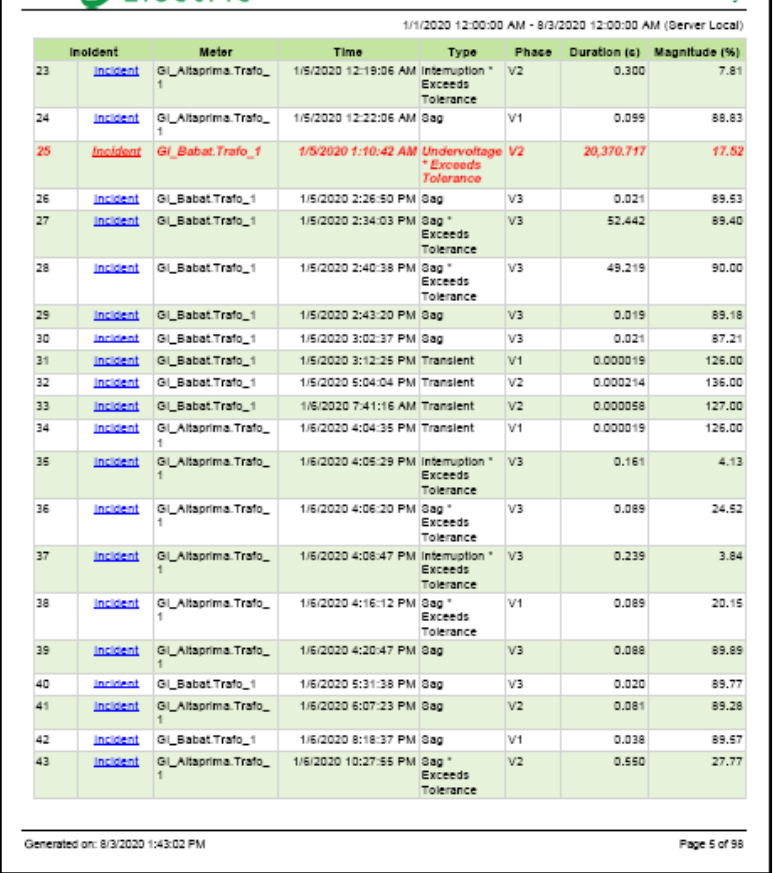

Gambar 11. Record gangguan TT bagian 4

\section{Schneider}

Power Quality

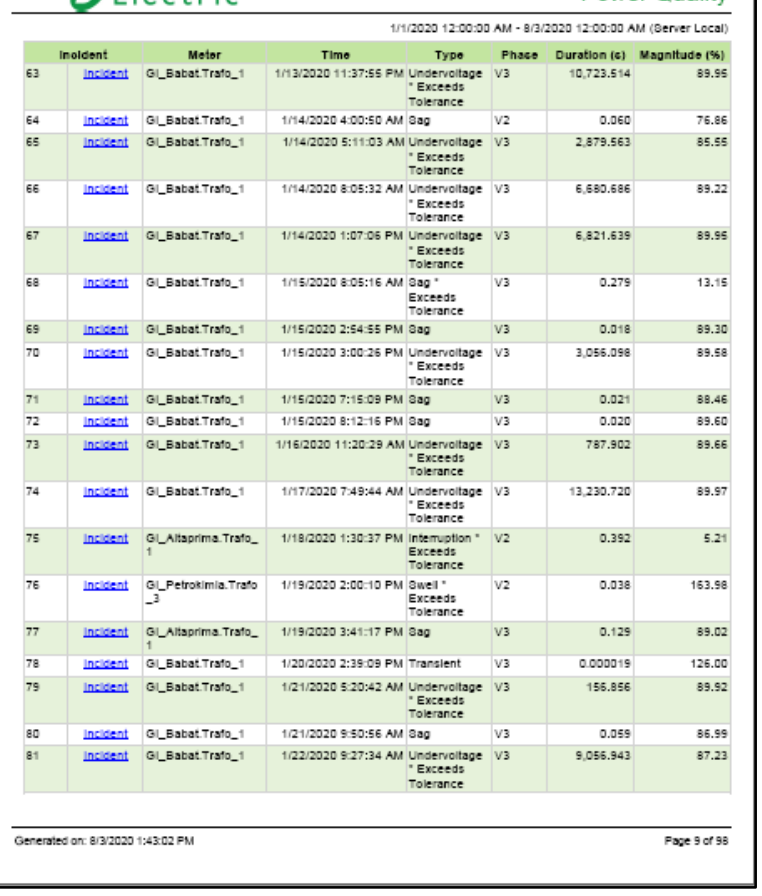

Gambar 12. Record gangguan TT bagian 5 


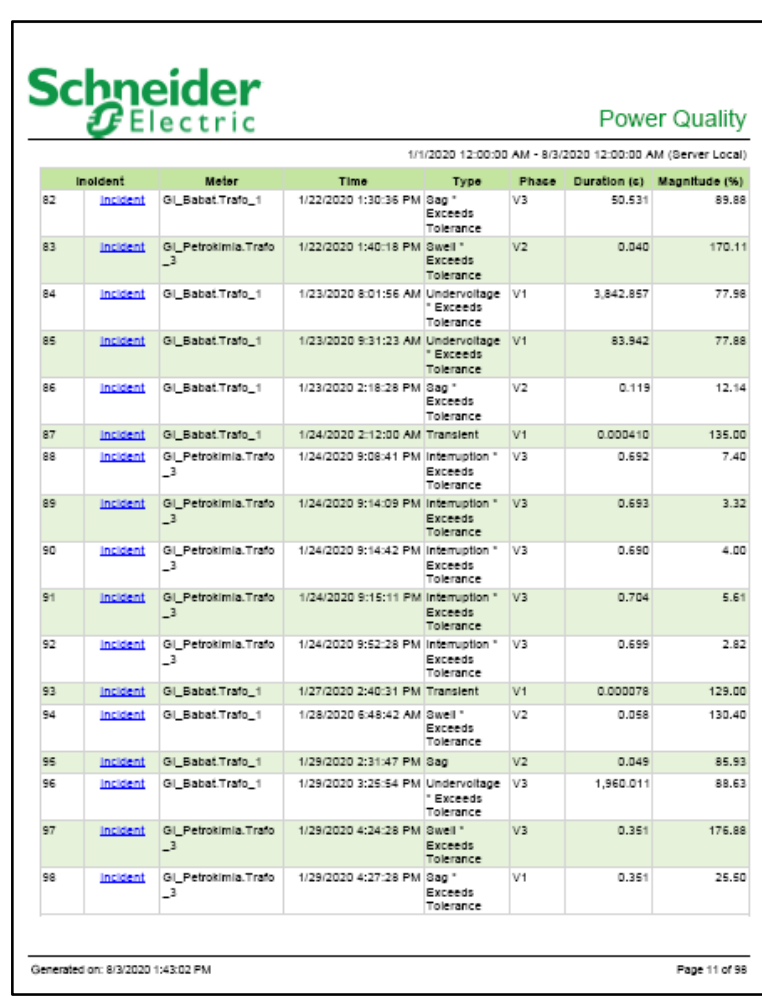

Gambar 13. Record gangguan TT bagian 6

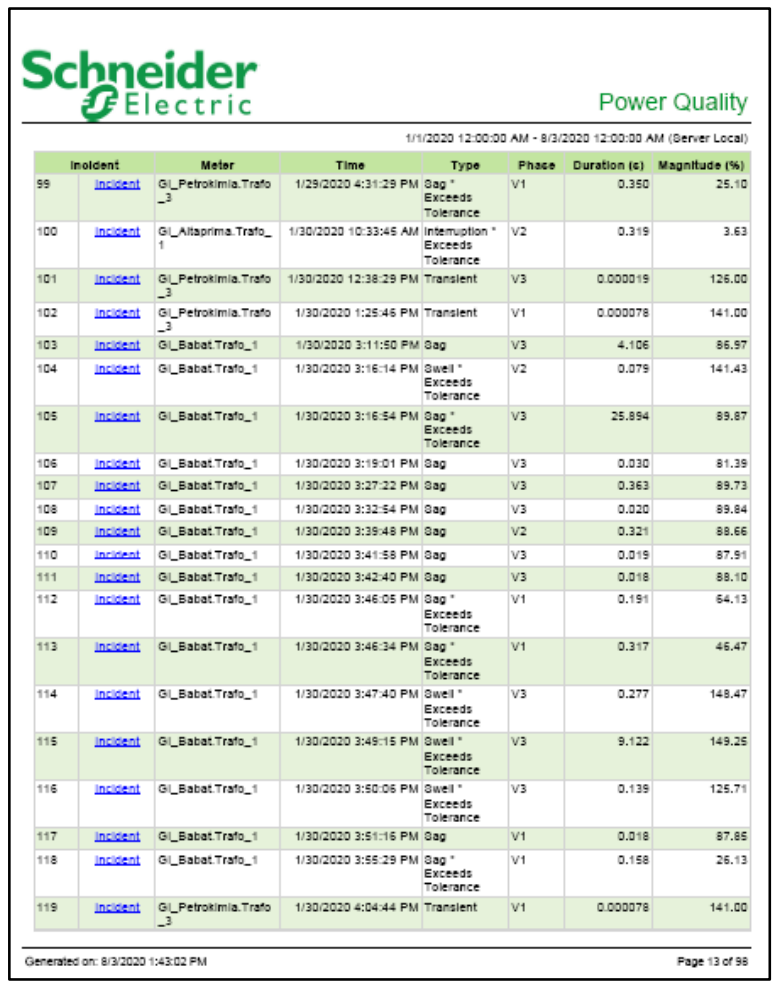

Gambar 14. Record gangguan TT bagian 7

Pada gambar 8 sampai gambar 14 [14] menunjukkan sebagian record fluktuasi tegangan di sistem PLN di Jawa Timur. Dari data yang kami dapatkan setidaknya terjadi lebih dari 50 kali dip tegangan dengan nilai penurunan tegangan yang hanya menyisakan kurang dari $10 \%$ dari tegangan nominal. Data tersebut belum mencakup kejadian dip akibat dari gangguan yang terjadi pada sisi $20 \mathrm{kV}$.

Efek yang ditimbulkan oleh kasus ini adalah dip voltage yang sangat tajam dengan waktu yang sangat cepat, tentu saja itu akan sangat mempengaruhi kinerja ATS yang ada dimana sensor tegangan sudah mendeteksi adanya tegangan yang turun sehingga memerintahkan CB untuk lepas pada penyulang utama, setelah CB pada penyulang utama lepas sempurna perintah selanjutnya adalah memasukkan CB pada penyulang backup. Ditengah kejadian tersebut untuk tegangan sudah normal sehingga perintah untuk memasukkan CB penyulang backup tidak tersalurkan, akibatnya kedua incoming berada pada kondisi open dan menyebabkan pelanggan padam karena supply yang terhenti. Ide perbaikan untuk hal tersebut kami dapatkan dengan menambahkan PLC pada sistem perintah sehingga dapat memberikan delay pada sistem perintah tersebut.

Dilihat pada gambar 8 sampai 14 diatas untuk dip voltage yang disebabkan oleh TT paling sering terjadi dengan kurun waktu antara 0.1 detik sampai dengan 1 detik padahal untuk waktu kerja ATS sendiri berkisar 0.3 detik untuk open dan 0.3 detik untuk close, maka dari data tersebut perintah untuk close dan open seharusnya dapat bertahan paling tidak selama 1 detik sehingga siklus open pada penyulang utama dan close pada penyulang backup dapat bekerja dengan baik. Dengan pertimbangan tersebut maka setting time delay yang kami terapkan adalah selama 1 detik.

Setelah kami terapkan beberapa perbaikan yaitu dengan rewiring dan memasang delay pada perintah, kegagalan kineja ATS akibat gangguan pada sistem dapat diminimalisir bahkan dihilangkan, dapat dilihat pada tabel 2 [15] berikut.

Tabel 2. Perbandingan sebelum dan sesudah perbaikan ATS

\begin{tabular}{|c|c|c|c|c|c|}
\hline No & Tanggal & Penyulang & Jam & Relay & Akibat yang ditimbulkan \\
\hline 1 & $11-02-2019$ & Suci & 22:52:00 & OCR & Icon Mall gagal switch \\
\hline 2 & $17-02-2019$ & Panca Putra & 9:00:00 & OCR-INST & Petro Oxo \& Bumi Mulia dip \\
\hline 3 & $25-02-2019$ & Suci & 11:52:00 & DGR & Gresmall Gagal switch \\
\hline 4 & 13-03-2019 & Tridharma & 16:33:00 & OCR-INST & Petro Oxo \& Bumi Mulia dip \\
\hline 5 & $31-12-2019$ & Suci & 21:23:00 & $\mathrm{EF}$ & Gresmall Gagal switch \\
\hline 6 & $10-01-2020$ & Suci & 22:07:00 & & Gresmall Gagal switch \\
\hline 7 & $25-02-2020$ & Panca Putra & 16:43:00 & OCR-INST & Bumi Mulia gagal Switch \\
\hline 8 & $08-04-2020$ & Suci & 22:21:00 & EF & Gresmall Gagal switch \\
\hline 9 & $09-05-2020$ & Panca Putra & 10:22:00 & OCR-INST & Petro Oxo \& Bumi Mulia dip \\
\hline 10 & $10-06-2020$ & Patra Raya & 10:03:00 & OCR-INST & Putro Lingkungan gagal switch \\
\hline \multicolumn{6}{|c|}{ Setelah Perbaikan pada ATS } \\
\hline 11 & $05-07-2020$ & Suci & 17:16:00 & OCR & nihil \\
\hline 12 & $15-07-2020$ & Patra Raya & 4:09:00 & EF & nihil \\
\hline 13 & $05-08-2020$ & Suci & $18: 27: 00$ & OCR-INST & nihil \\
\hline 14 & $06-08-2020$ & Patra Raya & 15:08:00 & EF & nihil \\
\hline 15 & $11-08-2020$ & Patra Raya & 19:38:00 & OCR & nihil \\
\hline 16 & $12-08-2020$ & Suci & 13:30:00 & & nihil \\
\hline 17 & $31-08-2020$ & Panca Putra & 9:10:00 & OCR-INST & nihil \\
\hline 18 & $13-09-2020$ & Patra Raya & $14: 45: 00$ & OCR-EF & nihil \\
\hline 19 & $17-09-2020$ & Patra Raya & 16:18:00 & EF & nihil \\
\hline 20 & $24-10-2020$ & Patra Raya & $16: 34: 00$ & OCR & nihil \\
\hline 21 & $27-10-2020$ & Patra Raya & 13:54:00 & OCR-INST & nihil \\
\hline 22 & $29-10-2020$ & Patra Raya & 4:09:00 & EF & nihil \\
\hline 23 & $30-10-2020$ & Tridharma & $10: 46: 00$ & OCR-INST & nihil \\
\hline
\end{tabular}




\section{Kesimpulan}

Dalam penelitian kali ini dapat disimpulkan bahwa untuk menangani gagal kerja dari ATS diperlukan:

1. Melaksanakan Rewiring guna memindahkan supply moto untuk menghindari UPS yang drop.

2. Menambahkan sistem interlocking permisive pada kedua incoming supply baik yang utama maupun yang backup.

3. Menambahkan PLC dengan setting time delay pada PLC guna menuntaskan siklus perintah yang sering gagal karena dip tegangan.

4. Perbaikan pada point 1 sampai 3 berjalan sukses untuk mengantisipasi kegagalan kerja ATS akibat gangguan pada sistem.

\section{Ucapan Terimakasih}

Puji syukur kami haturkan kepada Allah SWT dan junjungan kita Nabi besar Muhammad SAW, karena dengan hidayah dan inayah serta bimbingannya kami dapat menyelesaikan terselesaikannya jurnal penelitian ini. Dan tak lupa juga kami sampaikan terimakasih sebesar-besarnya kepada:

1. Rini Puji Astutik, ST,.MT selaku Dosen pembimbing yang telah memberikan bimbimngan dan petunjuk dengan penuh kesabaran dan setulus hati memberi saran.

2. Bapak-ibu Dosen Pendidikan Teknik Elektro yang memberikan ilmu selama kuliah

3. PT. PLN (Persero) UP3 Gresik yang bersedia memberikan ijin untuk melakukan penelitian dan pengambilan data.

4. Kepada orang tua, saudara dan teman yang senantiasa memberikan semangan dan motivasi.
[2] H. Ashour, "Automatic Transfer Switch (ATS) Using Programmable Logic Controller," Arab Academy for Science \& Technology Istanbul, turkey, 2004.

[3] E. Susanto, "Automatic transfer Switch (Suatu Tinjauan)," Jurnal Teknik Elektro, vol. 5, no. 1, pp. 1-4, 2013.

[4] y. fikra, D. Suryadi and R. R. Yacoub, "RANCANG BANGUN AUTOMATIC TRANSFER SWITCH (ATS) DENGAN PARAMETER ARUS, FREKUENSI DAN SUHU," Teknik Elektro Fakultas Teknik UNTAN Pontianak, 2016.

[5] P. H. Ginting and E. W. Sinuraya, "PERANCANGAN AUTOMATIC TRANSFER SWITCH (ATS) PARAMETER TRANSISI BERUPA TEGANGAN DAN FREKUENSI DENGAN MIKROKONTROLER ATMEGA 16," TRANSMISI, vol. 16, no. 3, 2014.

[6] M. Inta and M. I. Sikki, "SISTEM AUTOMATIC TRANSFER SWITCH (ATS) AUTOMATIC MAIN FAILURE (AMF) MENGGUNAKAN SMS," JREC Journal of Electrical and Electronics, vol. 6, no. 1.

[7] R. Pakpahan, D. N. Ramadan and S. Hadiyoso, "RANCANG BANGUN DAN IMPLEMENTASI AUTOMATIC TRANSFER SWITCH (ATS) MENGGUNAKAN ARDUINO UNO DAN RELAI," JETT Jurnal Elektro Telekomunikasi Terapan, pp. 1-10, 2016.

[8] PT PLN (Persero) Pusat Pendidikan dan Pelatihan, Power Quality, Jakarta : PLN Pusdiklat, 2010.

[9] N. Fahrezi, "academia - Materi PLC," 2020. [Online]. Available: https://www.academia.edu/28486949/MATERI_PLC?auto=download. [Accessed 2406 2020].

[10] T. U. Haryanto, "Pengertian PLC (Programmable Logic Control)," 03 April 2013. [Online]. Available: http://sukasukapaktri.blogspot.com/2013/04/pengertian-plcprogrammable-logic.html. [Accessed 2406 2020].

[11] PT PLN (Persero) UP3 Gresik, "Data Gangguan Semester 1 2020," PT PLN (Persero) UP3 Gresik, Gresik, 2020.

[12] M. Mahachandra, W. Situmorang and N. U. Handayani, "IMPLEMENTASI 5S DENGAN TEKNIK ROOT CAUSE PROBLEM SOLVING PADA GUDANG LOGISTIK PT. PLN (PERSERO) AREA LUBUK PAKAM," Seminar Nasional IENACO, vol. 2337, no. 4349, pp. 1-6, 2019.

[13] R. C. Dugan, M. F. McGranaghan, S. Santoso and H. W. Beaty, Electrical Power Systems Quality, Pennsylvania: McGraw Hill Profesional, 1996.

[14] PT PLN (Persero) UP2D Jatim, "Data Power Quality Meter Gardu Induk di Jawa Timur," PT PLN (Persero) UP2D Jatim, Surabaya, 2020.

[15] PT PLN (Persero) UP3 Gresik, "Data Gangguan penyulang 2020," PT PLN (Persero) UP3 Gresik, Gresik, 2020.

\section{Daftar Rujukan}

[1] PT PLN (Persero) Distribusi Jawa Timur, "Standart Operating Procedure (SOP) Pelaksanaan Layanan Premium," Surat Dinas, pp. 1-13, 2018. 